\title{
Europæiske arbejdsmarkedsforskere samlet til IIRA kongres i København
}

Andersen, Søren Kaj; Hansen, Lise Lotte; Navrbjerg, Steen Erik; Mailand, Mikkel

Published in:

Tidsskrift for Arbejdsliv

Publication date:

2011

Document version

Også kaldet Forlagets PDF

Citation for published version (APA):

Andersen, S. K., Hansen, L. L., Navrbjerg, S. E., \& Mailand, M. (2011). Europæiske arbejdsmarkedsforskere samlet til IIRA kongres i København. Tidsskrift for Arbejdsliv, 13(1), 103-107. http://www.nyt-omarbejdsliv.dk/images/pdf/2011/nr1/tfa1_2011_103-107.pdf 


\title{
Europæiske arbejdsmarkedsforskere samlet til IIRA kongres i København
}

\author{
Søren Kaj Andersen, Lise Lotte Hansen, Steen E. Navrbjerg \& Mikkel Mailand
}

$\mathrm{I}$ dagene 28. juni til 1. juli 2010 blev den 9. europæiske International Industrial Relations Association, IIRA, kongres afholdt i København. Det bragte 370 arbejdsmarkedsforskere og praktikere fra 32 lande til den fire dage lange kongres. IIRA er organiseret inden for rammerne af ILO og med eget sekretariat placeret i Geneve. Et hovedformål med IIRA er at formidle viden om forskning og uddannelse vedrørende arbejdsmarkedsregulering - og et centralt element i dette virke er regionale såvel som globale kongresser.

Kongressen i København samledes under det overordnede tema European Employment Relations - Crises and Visions. Dette tema blev fastlagt af den akademiske styregruppe bag kongressen, som bestod af arbejdsmarkedsforskere fra København Universitet, Roskilde Universitet, Syddansk Universitet og Aalborg Universitet. Vært for kongressen var Forskningscenter for Arbejdsmarkedsog Organisationsstudier, FAOS, København Universitet. Det var den akademiske styregruppe, der stod bag tilrettelæggelsen af kongressens program, som blev organiseret i fire parallelle spor med op til seks workshops i hvert spor. Cirka 180 abstracts var blevet sendt ind med henblik på præsentation af fuldt paper. Lige godt $100 \mathrm{blev}$ udvalgt af styregruppen til præsentation i workshop. Særligt udvalgte papers fra de fire nedenfor beskrevne spor blev præsenteret ved plenarmøder.

\section{Spor 1:}

The diverse labour force - new and old challenges

Temaet handlede om de nye udfordringer, som følger af den stigende diversitet mellem arbejdstagere og i arbejdsmarkedsrelationerne skabt af globaliseringen herunder især arbejdsmigration og den nye 'fleksible kapitalisme'. Diversitet var valgt frem for blot køn eller etnicitet med det ønske at afspejle udviklingen i kønsforskningen, hvor fokus i stadig højere grad er på mangfoldighed og på samspillet mellem forskellige kategorier som fx køn, etnicitet og klasse. Desuden var hensigten at få kønsforskningen i dialog med de andre diskussioner inden for IR-traditionen. Endelig kan man hævde, at diversitet og differentiering vel nok er de mest fremtrædende træk på arbejdsmarkedet og i arbejdsmarkedsrelationerne i dag. Ønsket var dog ikke kun at sætte fokus på det nye, da gamle diversitetsproblematikker som for eksempel uligeløn, kvinders underrepræsentation i fagforeningsledelse og arbejds-familielivskonflikter forsat er til stede og ikke mindst risikerer at blive forstærket som følge af den finansielle krise.

Det blev et spor, der tiltrak mange papers. Det betød desværre også, at ikke alle 
papers kunne præsenteres i workshops, og at programmet i nogle workshops var presset. Til gengæld var der mange spændende præsentationer og mange gode kommentarer fra deltagerne.

Over halvdelen af alle af papers faldt inden for tre hovedområder: migrantarbejdere, køn (primært kvinder) og fagforeninger. De tre papers, der blev udvalgt til plenar præsentation, repræsenterede nye tendenser inden for forskningen. Det første af Heather Connolly og Miguel Martínes Lucio, University of Manchester, handlede om fagforeningssvar på migration i Europa, og på hvorledes inkluderende kategorier om migration er blevet udviklet. Det andet skrevet af Janine Leschke og Maria Jepsen, ETUI, var en komparativ analyse af tre europæiske lande med fokus på konsekvenserne af den finansielle krise for ligestillingen mellem kvinder og mænd. Og det tredje som diskuterede maskulinitet og fleksibelt arbejde, var skrevet af Amanda Thompson, De Montfort University. Derudover var der tre overordnede temaer: 'atypisk' arbejde og nye typer ansættelsesforhold, nye og gamle udfordringer til regulering og diskussioner af IR-traditionen. På tværs af de forskellige temaer løb en række fælles og delvist overlappende diskussioner om social inklusion og solidaritet på arbejdspladsen og i fagforeninger, om betydningen af læring og uddannelse for såvel den enkelte arbejdstager som for at skabe fællesskaber mellem arbejdstagere, om organiseringsstrategier og andre fornyelsesstrategier, om både barrierer for og støtte til unge mennesker og migrantarbejderes aktive medlemskab og til kvinders lederskab i fagforeninger, om forskellighed inden for grupper fx blandt migrantarbejdere og konsekvenserne heraf for interesserepræsentation, kollektivisme og organisering samt om grupper af arbejdstageres eksklusion fra/ problemer med regulering, rettigheder, aftaler, fagforeninger og politikker.

\section{Spor 2: \\ Workplace relations and HRM - back to collectivism?}

Dette spor havde til formål at belyse, om relationerne mellem ledelse og medarbejdere har ændret sig - særligt i hvilket omfang den globale finanskrisen skaber nye relationer mellem ledelse og medarbejdere. HRM har haft en betydelig indflydelse over de seneste 15 år og har i mange sammenhænge spillet sammen med en decentralisering og individualisering af forhandlingsrelationerne, hvilket har været medvirkende til at svække de faglige organisationer i mange lande. Krisen har givet ledersiden nye muligheder for at presse løn og arbejdsvilkår - men har det også ført til et svar på medarbejdersiden i form af en revitalisering af den kollektive repræsentation og de faglige organisationer?

De knap 30 papers, der indgik i dette spor, var for langt de flestes vedkommende virksomhedsnære empiriske studier, hvilket ligger i naturlig forlængelse af temaet for dette spor. De bredte sig fra lønsystemer over de psykologiske kontrakter i nye HR-teknikker til medarbejderinvolvering både i organiseringen af arbejdet og i bestyrelser. Kun et par papers prøvede at lægge arm med mere teoretiske aspekter af virksomhedsstudierne, og det er måske nok en typisk svaghed ved de virksomhedsnære beskrivelser; ofte er indsamlingen og behandlingen af de store datamængder - uanset om de er kvalitative eller kvantitative - så krævende, at forskerne ikke har ressourcerne til at løfte analyserne til mere teoretiske overvejelser. Det gjorde ikke de mange papers mindre interessante - men generaliserbarheden af de fundne resultater kan være begrænset, når der ikke i højere grad arbejdes med teorigenerering.

Også de tre udvalgte plenar-præsentationer var papers baseret på empiriske studier. Anna Ilsøes fra FAOS, Københavns Universitet, diskuterede i sin plenarpræsenta- 
tion, om de mere fleksible reguleringer af arbejdstiderne er et tveægget sværd; på den ene side giver det muligheder for at afbalancere familie-arbejdsliv, men det kan på den anden side også blive brugt af arbejdsgivere til at differentiere mellem dem blandt arbejdstagerne, der kan levere fleksibilitet,og dem, der ikke kan. Eivind Falkum, Inger Marie Hagen og Sissel Charlotte Trygstad diskuterede i deres plenumpræsentation, om fagforeninger i Norge betyder noget for graden af demokratisering på arbejdspladsen. Deres konklusion er, at der er meget lille forskel på graden af medindflydelse på arbejdspladser med henholdsvis uden faglig repræsentation. Endelig præsenterede Jeremy Waddington fra ETUI/University of Manchester i sin plenarpræsentation et internationalt data-sæt om europæiske fagforeningsmedlemmers meget forskellige opfattelse af fagforeningerne og deres arbejde. Det kunne konstateres, at en diskussion af den globale krises betydning for samarbejdsrelationerne på virksomhedsplan måske kom lige tidligt nok for mange studier; kun et par papers adresserede krisen som sådan. Derfor forblev spørgsmålet stillet i overskriften - hvorvidt de kollektive repræsentationer igen bliver styrket som følge af krisen - i det store og hele ubesvaret.

\section{Spor 3:}

Employment policies - labour demand, demography and social partners

Fokus var her på beskæftigelsespolitik i bred forstand og de udfordringer, politikken aktuelt stilles over for. De mere end 30 papers fordelte sig i det store hele i tre grupperinger om henholdsvis flexicurity, beskæftigelsespolitik i bred forstand samt fagforeninger. Mht. det første emne, flexicurity, var der ikke overraskende en del bidrag, der inkluderede Danmark i analysen. Efter at have været branchens kæledække i mange år er humlebien nu kommet ned på jorden, og flere papers og kommentarer stillede spørgsmålstegn ved den danske flexicurity models positive karakteristika, nu hvor arbejdsløsheden er tredoblet. Også variationen i løn- og arbejdsvilkår for forskellige lønmodtagergruppe blev diskuteret. Endelig stillede Maarten Keune fra Universitet i Amsterdam i sit plenar-oplæg spørgsmål ved den analytiske kapacitet i begrebet, som han fandt for bredt og ikke tilstrækkeligt klart defineret og endvidere åbent for politisk brug og misbrug.

Blandt de beskæftigelsespolitiske bidrag var Jason Heyes, Birmingham Universitetet, der i sit plenar oplæg diskuterede den rolle som forskellige former for uddannelse og efteruddannelse har spillet i EU medlemsstaternes respons på den økonomiske krise. Det viser sig, at de fleste medlemsstater i mindre grad end tidligere anvender (efter)uddannelse som beskæftigelsespolitisk redskab, selvom der er gode argumenter for at satse mere her i en økonomisk lavkonjunktur.

Flere af papers med relation til det tredje emne om fagforeninger adresserede de mange udfordringer, fagforeningerne står overfor på det europæiske arbejdsmarked i dag, herunder medlemstilbagegang og det medfølgende behov for fusioner samt konkurrencen fra alternative lønmodtagerorganisationer.

\section{Spor 4: Regulating employment in Europe - processes, actors and governance}

Dette spor omhandlede reguleringen af arbejdsmarkedsrelationer bredt og de involverede aktører og processer. En større gruppe papers fokuserede på kollektive forhandlinger og her særligt decentraliseringen af forhandlingskompetence i forskellige europæiske stater samt de konsekvenser det har haft. Herunder også hvordan arbejdsgivere har valgt forskellige strategier; fra at forlade kollektive aftalesystemer til at udvikle den 
organiserede eller centraliserede decentralisering sammen med lønmodtagersiden. En anden større gruppe papers omhandlede de faglige organisationers roller og strategier. Herunder radikalisering af franske og britiske faglige organisationer - et fænomen som dog fremstår som marginalt i det brede europæiske billede. Knyttet hertil præsenterede John Kelly, University of London, og Kirstin Hamann, University of Central Florida, et plenar paper om generalstrejker i Vesteuropa gennem 3 årtier. Hovedpointen var, at trods en overordnet tendens til faldende strejkeaktivitet, så er omfanget af protester mod siddende regeringers økonomiske politik steget siden 1980'erne - heraf en stigning i antallet af generalstrejker. Det er særligt de sydeuropæiske lande - ikke mindst Grækenland - der tegner denne tendens.

Et tredje fremtrædende emne var den europæiske regulering, herunder resultater af arbejdsmarkedets parters dialog på EUniveau; den sociale dialog. Et af emnerne, Europæiske Samarbejdsudvalg, blev taget op i et plenarpaper af Michael Whittall, Stefan Lücking og Rainer Trinczek, Technische Universität Munchen/Universität ErlangenNürnberg. Deres studie viser, at manglende forventninger til resultater betyder, at der oprettes forholdsvis få Europæiske Samarbejdsudvalg i Tyske koncerner. Samme skepsis findes ikke i Storbritannien - her er snarere tale om et generelt ukendskab til reguleringen om sådanne samarbejdsudvalg, hvilket forfatterne ser som en effekt af den svagt udviklede medarbejderrepræsentation i Storbritannien.

Omkring en håndfuld papers beskæftigede sig med udvikling i regulering, fagforeninger og partsrelationer i Øst- og Centraleuropa. Dette er glædeligt ud fra en betragtning om, at det forsat er begrænset, hvad der kommer af studier om arbejdsmarkedsrelationer fra disse lande. Denne forskningstradition står ikke stærkt i denne del af Europa, hvorfor det stadig ofte er vesteuropæere, der præger forskningen på området.

Endelig kan det bemærkes, at der var papers, som behandlede samspillet mellem de finansielle markeder og arbejdsmarkeder. Tydeligt foranlediget af finanskrisen er der opstået behov for en nærmere forståelse af, hvordan forandringer i den finansielle verden påvirker beskæftigelsen.

\section{Symposier}

Ud over de fire omtalte spor blev der afviklet en række sidestående aktiviteter. Væsentligst var her ni symposier, hvor resultater af forskellige primært internationalt forskningssamarbejder blev præsenteret. Emnerne strakte også her ganske vidt, dog med et par som førte flexicurity diskussionen videre, dels med de nordiske arbejdsmarkeder og arbejdskraftmobiliteten som omdrejningspunkt, dels med et mere generelt spørgsmål om det er på tide at forlade flexicurity og returnere til teorien om transitionelle arbejdsmarkeder. Yderligere var der et par symposier, der tog afsæt i krisen og spurgte til, hvordan man har søgt at reducere de beskæftigelsesmæssige konsekvenser af krisen i forskellige europæiske lande, samt hvordan krisen har påvirket HRM/IR på virksomhedsniveau.

De til sammen mere end 120 artikler og tekster, som ligger bag såvel workshop sporene som symposierne, kan hentes fra FAOS hjemmeside, http://faos.ku.dk/arrangementer/iira/.

På kongressens sidste dag blev det bekendtgjort, at organisationen IIRA skifter navn. Industrial relations omhandler grundlæggende kollektive aftalesystemer - også kendt som multi-employer bargaining. Gennem efterhånden lang tid har kollektive forhandlinger været et vigende fænomen i først og fremmest USA og Storbritannien, 
men også i flere andre europæiske lande. På den baggrund har der længe været et ønske om et nyt navn, der bygger på det bredere begreb employment relations - som kort sagt rummer alt fra reguleringen af det individuelle ansættelsesforhold til kollektive forhandlingssystemer. Det nye navn blev In- ternational Labour and Employment Relations Association, ILERA. Forhåbningen er, at det nye navn vil kunne tiltrække en bredere gruppe af arbejdsmarkedsforskere til organisationen. Afsluttende kan det nævnes, at den første ILERA verdenskongres afholdes i Philadelphia, USA, 2. til 5. juli 2012. 